Canadian University Music Review

Revue de musique des universités canadiennes

\title{
CanCon and the Canon
}

\section{Robin Elliott}

Volume 23, numéro 1-2, 2003

URI : https://id.erudit.org/iderudit/1014524ar

DOI : https://doi.org/10.7202/1014524ar

Aller au sommaire du numéro

Éditeur(s)

Canadian University Music Society / Société de musique des universités canadiennes

ISSN

0710-0353 (imprimé)

2291-2436 (numérique)

Découvrir la revue

Citer cet article

Elliott, R. (2003). CanCon and the Canon. Canadian University Music Review / Revue de musique des universités canadiennes, 23(1-2), 201-213.

https://doi.org/10.7202/1014524ar
Résumé de l'article

La musique canadienne est presque complètement exclue des manuels utilisés au niveau universitaire, dont la plupart sont publiés aux États-Unis. Dans un cours d'introduction à l'histoire, si le contenu canadien s'y trouve, il est généralement annexé à la fin de l'exposé chronologique. Le présent article plaide en faveur d'une approche différente qui intégrerait le contenu canadien dans toutes les époques du cours d'introduction, de l'Antiquité à nos jours. Les cours de base en ethnomusicologie pourraient également aborder la musique canadienne à de nombreux moments.
All Rights Reserved (C Canadian University Music Society / Société de musique des universités canadiennes, 2004
Ce document est protégé par la loi sur le droit d'auteur. L'utilisation des services d'Érudit (y compris la reproduction) est assujettie à sa politique d'utilisation que vous pouvez consulter en ligne.

https://apropos.erudit.org/fr/usagers/politique-dutilisation/ 


\section{CANCON AND THE CANON ${ }^{1}$}

\section{Robin Elliott}

Musicologists spend a lot of time teaching music history but very little time writing about music history pedagogy. Our colleagues in music education must puzzle over this fact, as must music theorists, who have a journal dedicated to pedagogy (called, appropriately enough, the Journal of Music Theory Pedagogy). But there are signs that musicologists are finally taking a serious interest in how music history is taught. An important book of essays published in 2002 explores some creative teaching approaches for a wide variety of music history courses at the undergraduate level in the United States (Natvig 2002). ${ }^{2}$ Inspired by this example, I would like to consider here the subject of music history pedagogy in Canada, and especially the role that Canadian materials might play in canonical survey courses.

In 1990 Beverley Diamond reported that Canadian music courses were being taught in only two dozen of the 41 music departments across Canada (Diamond 1990, 16). A survey conducted by the Canadian League of Composers more recently found that such courses are now on offer at 73 per cent of universitylevel institutions in the country (Roi 2003). This is an impressive record of growth, and it is encouraging that Canadian music is being taught from coast to coast in separate, specialized courses. But of equal or perhaps even greater importance is the integration of Canadian materials into the general music history survey - the two to four semester long mandatory undergraduate course in which a representative sample of canonical works in the Western art music tradition is studied.

Canadian music does not currently feature in the standard U.S. textbooks that are used for such survey courses. The Grout/Palisca(/Hanning) textbook, in its many editions and permutations since it was first published in 1960, has long been the frontrunner in terms of music history textbook sales in this country, but it has never appeared in a Canadian edition or featured any Canadian content. ${ }^{3}$ Other U.S. textbooks distributed in the Canadian market

1 This is such an important and timely topic in Canadian academe that we encourage readers to submit responses, which we will publish in the next number with the author's "responses to the responses."-Ed.

2 The book was used for an eight-week summer seminar on music history pedagogy in 2003 at the University of Northern Colorado (as reported by Jonathan Bellman on ams-1 on 27 August 2003) and for a "Teaching Music History Study Day" on 18 October 2003 at Michigan State University School of Music (as reported by Kathryn Lowerre on ams-1 on 27 October 2003). Among the suggestions brought forward during the latter event was a proposal for an American Musicological Society Study Group on Teaching.

3 The current editions are Grout and Palisca (2001) and Hanning (2002), based on Grout and 
have a similar record. The neglect of Canadian content seems almost purposeful in the most recent such book, A History of Music in Western Culture by Mark Evan Bonds: the author provides special treatment of 13 geographical regions in his coverage of twentieth-century music (including Latin America and the United States), but offers not a word on Canada (Bonds 2003). More specialized U.S. textbooks that deal with twentieth-century music are also silent on the contributions of Canadians. William Austin's 1966 textbook infamously dealt with Canadian music in a single, glaringly inaccurate sentence (Austin 1966, 450), ${ }^{4}$ but even Robert Morgan's newer textbook in the Norton series offers only a brief discussion of R. Murray Schafer by way of Canadian content (Morgan 1991, 454-55).

My intent in this article is not to offer another list of the dismal absences and inaccuracies of scholarship on Canadian music outside of this country. ${ }^{5}$ Instead I would like to consider how those of us who are teaching music history in Canada could add some Canadian content to our survey courses. The best possible solution, of course, would be for an enterprising Canadian publisher to commission a music history textbook by Canadian authors and with Canadian content for the Canadian market. ${ }^{6}$ Such a book would take cognizance of the fact that teaching music history in Halifax, Toronto or Vancouver is not the same thing as teaching music history in Boston, Rochester or Seattle. It is interesting that the much smaller French language market in Canada does have such a book. Initiation à la littérature musicale arose from an initiative of the Quebec Ministry of Education; it offers a survey of Western art music in 14 chapters, and ends with a 40-page chapter on music in Quebec by Louise Bail Milot (Paul, Bail Milot, and Hirbour 1987). The easy availability of U.S. textbooks seems to have prevented scholars and publishers from tackling a similar project for the English-language market in Canada.

The usual approach for incorporating Canadian content in music history survey courses has traditionally been to substitute a few token Canadian pieces in place of (or in addition to) works by U.S. composers in the section on the twentieth century (or rather "The American Twentieth Century," as Grout/Palisca/Hanning terms it [Hanning 2002, chap. 22]). This ghettoization of Canadian music has strong pedagogical implications: it sends the message that music arrived only recently in this country, and thus exists outside of (or at best at the very end of the chronological progression of history. Beverley Diamond has observed a similar narrative agenda in the treatment of Native music in both Canadian and U.S. music textbooks: "Native music cultures are consistently treated without historical specificity and are isolated from the rest

Palisca (2001). Norton did commission McGee (1985) to compensate for the lack of Canadian music content in its other textbooks.

4 The sentence was neatly dissected by John Beckwith $(1969,11-12 ; 1997,45)$.

5 I note, though, that it is time for another update to John Beckwith's two "P. R. failure" articles, which appeared in 1969 and 1986 respectively $(1997,35-49,111-21)$.

6 Lopinski, Ringhofer, and Zarins (2002-3) includes Canadian materials in two of the volumes, but it is intended for use by pupils of the Royal Conservatory of Music and is not at all appropriate for university-level music history courses. 
of the story" (Diamond 1994, 161; McGee 1995, 294). Canadian music-and Native music-deserve better than this.

The situation in Canada today in many ways parallels the case in the United States for much of the twentieth century, when general music history textbooks offered little or no American content. This was a reflection of the Eurocentric bias of the discipline of musicology in its formative stages in North America, and of the guiding influence of a generation of émigré scholars. To address this issue, the Sonneck Society formed a Committee on American Music in American Schools and Colleges, and in 1991 the committee issued a 16-page pamphlet titled Bringing Music History Home: A Guide for American Teachers of Music History. ${ }^{7}$ The pamphlet suggests 22 ways that American content can be inserted not just at the end of a survey course, but continuously, from the medieval era onwards. The linkage is not always chronological: the pamphlet suggests, for instance, that in dealing with successive (as opposed to simultaneous) compositional practices in medieval Europe, the instructor could point out that the same procedure is used in eighteenth-century American fuging tunes. In a similar vein, the pamphlet suggests that a class on Bach could spend time on the discovery and reception of Bach's music in America, from the nineteenth century to the present. In the spirit of Bringing Music History Home, I offer here a few suggestions for ways that Canadian music could be incorporated into a music history survey course at various points in the curriculum.

\section{Medieval Music}

Marius Barbeau was convinced that the origins of the Quebec folksong repertory that he collected, transcribed, and studied lay with the jongleurs of medieval France. Janet McNaughton (1984, 60-64) and John Haines (1999, 1-6; forthcoming) have both written about Barbeau and his relationship to medieval music. The varying roles that orality and literacy have played in medieval music and in Quebec folksong could profitably be compared in light of Barbeau's theories and beliefs. Barbeau also contributed to the revival (or rather the introduction) of medieval and Renaissance music in Canada. It was at his initiative that the Canadian Folk Song and Handicraft Festival held in Quebec City in 1927 featured madrigals by Jannequin, Goudimel, and Costeley, and also a performance (said to be the first in modern times) of Adam de la Halle's Jeu de Robin et de Marion in a production supervised by and using the edition of Jean Beck (Lazarevich 1996, 6). Consideration of this 1927 festival could lead to broader issues about "the modern invention of medieval music" (Leech-Wilkinson 2002).

7 I have not seen the original pamphlet, but J. Bunker Clark made an updated version of it available online at http://people.ku.edu/ bclark/grouttoc.html (accessed 8 February 2004; Clark died 26 December 2003). 


\section{RenAISSANCE MUSIC}

European music history begins to intersect in an important way with Canada beginning in the sixteenth century. Helmut Kallmann's A History of Music in Canada 1534-1914 (1960; repr. 1987) provides examples of sixteenth and early-seventeenth century music making in Canada that could be discussed in terms of European music of the period. An obvious point, but a noteworthy one, is that the Renaissance was the great European age of exploration: Jacques Cartier and Claudin de Sermisy were almost exact contemporaries, as were Samuel de Champlain and Claudio Monteverdi.

The choral music of Healey Willan often draws upon medieval and Renaissance music for its inspiration. Willan adapted music from the Graduale Romanum to create English plainsong for his Ritual Choir at the Church of St. Mary Magdalene beginning in the $1920 \mathrm{~s},{ }^{8}$ and that church's Gallery Choir often sang music by English Renaissance composers as well as original works by Willan modelled (in part) on that repertoire. Listening to and analyzing Willan's music carefully will allow students to reflect upon how and why it sounds different from his medieval and Renaissance models, and will ideally lead to a deeper understanding not just of Willan but of early music as well.

\section{French Baroque MuSIC}

The scholarship of Élisabeth Gallat-Morin and Erich Schwandt, among others, has shed much light on music making in New France (see Gallat-Morin and Pinson 2003). Nearly four hundred pieces of French baroque organ repertoire, including works by Nicolas Lebègue (ca. 1631-1702) are preserved in a manuscript collection known as Le livre d'orgue de Montréal. The 540-page manuscript was rediscovered in 1979, and has subsequently been published in facsimile and in a critical edition (in three volumes) by Gallat-Morin and Kenneth Gilbert (1985-88); Gallat-Morin $(1981,1988)$ has also written a major study of the manuscript and its music. Selections from Le livre d'orgue de Montréal have been recorded by Kenneth Gilbert, Réjean Poirier, and Yves-G. Préfontaine. ${ }^{9}$ Discussion of Le livre d'orgue de Montréal could lead to a general consideration of source studies and the early music revival, or of centre versus margins in Baroque musical culture.

\section{Classical ERa}

Chamber music by Haydn, Mozart, and their contemporaries was performed in Halifax and Quebec City in the late-eighteenth century (Elliott 1990, 5-9).

8 Listen, for example, to the Mode VII Introit "Unto us a Child is born" for Christmas Day (transcribed by Willan from the Graduale Romanum) as sung by the Ritual Choir of the Church of St. Mary Magdalene under Robert Hunter Bell on Virgin Classics CD VC 5451092 (1994). The recording also includes choral pieces in Willan's "Renaissance" style (e.g. O Trinity, most Blessed Light, HWC 309) and other pieces that include a variety of influences ranging from fauxbourdon to Russian choral music and even jazz.

9 Gilbert recorded 21 works on 2 CDs in 1983 on Analekta AN 2 8214-5; Poirier recorded 7 works in 1987 on Ariane / Scalen Disc ARI 140; and Préfontaine recorded one work in 1996 on Atma ACD 2 2120 . 
Two works of music theatre that were composed in Canada at this time are Joseph Quesnel's Colas et Colinette (premiered in Montreal in January 1790, the same month that Cosi fan tutte was premiered in Vienna) ${ }^{10}$ and Lucas et Cécile (possibly not performed before the twentieth century), which have been issued in editions by Godfrey Ridout (Quesnel 1974) and John Beckwith (Quesnel 1992) respectively. ${ }^{11}$ The relationship between Colas et Colinette and Jean-Jacques Rousseau's Le Devin du village is the subject of a study by Lucien Poirier $(1988,60-66)$. These two works by Quesnel provide a good opportunity to discuss issues of musical transmission; both works fell into neglect and much of the source material was lost after Quesnel's death in 1809.

\section{BEETHOVEN}

T. F. Molt, a native of Stuttgart, settled in Quebec in 1822; in 1825 he visited Beethoven and requested a piece of music as a souvenir. Beethoven complied and wrote a short canon for Molt on the text "Freu dich des Lebens" (WoO 195); this was the composer's only known contact with the New World. ${ }^{12}$ The holograph of the canon for Molt is now in the collection of the Library and Archives of Canada, and it has inspired Alexander Brott's Paraphrase in Polyphony for orchestra, and also string quartet pieces by the Ottawa composers Patrick Cardy, Eldon Rathburn, Clifford Ford, Gilles Leclerc, and Jan Jarvlepp. ${ }^{13}$ Of related interest is John Oswald's preLieu, an intertextual gloss on the "Alla danza tedesca" movement of the String Quartet in B-flat major, Op. 130.14

\section{NINETEENTH-CENTURY MUSIC}

Calixa Lavallée studied in Paris from 1873 to 1875 with Antoine-François Marmontel, who was also Claude Debussy's teacher at the time. Lavallée's piano etude Le Papillon, Op. 18 (recorded several times by different pianists)

10 A substitute aria for Cosi fan tutte, "Rivolgete a lui lo sguardo," includes the phrase "che gli uguali non si trovano da Vienna al Canada" ("whose like you will not find from Vienna to Canada"). And further on the subject of trivia: Mozart, Saskatchewan may be the only town in the world named after that composer.

11 An abridged LP recording of Colas et Colinette was made in 1968 (RCI 234 / Select Records CC-15.001) and several excerpts from Lucas et Cécile are available on CD. A complete recording of both works is long overdue.

12 See the pamphlet Beethoven \& Quebec (1966), which includes a reproduction of the single-page holograph. Clayton (2003) also includes a reproduction of the holograph. See also Kallmann (1971: 107-17), which includes a reproduction of the canon, some notes on Beethoven reception in Canada, and an interesting account of Ludwig Johann van Beethoven, the son of Beethoven's nephew Karl, who lived in Montreal and Toronto in the early 1870 s.

13 Brott's Paraphrase in Polyphony was recorded in 1967 by the Orchestre de Radio-Canada under Brott's direction (RCI 235 / Select CC-15.088 / Anthology of Canadian Music 20); Jarvlepp's piece, in a live performance by the Madawaska String Quartet that was broadcast on the CBC, can be downloaded at http://www.toronto.cbc.ca/musicaroundus/madawaska.html (accessed 8 February 2004).

14 preLieu is from Lieu dWig Wand/Bay/Tow $v \&$ (pronounced Ludwig van Beethoven), a suite of pieces written for the Kronos Quartet in 1991. Two movements, $v \&$ and preLieu, in performances by the Kronos Quartet and the Modern Quartet respectively, are available on the 2-CD set 69 Plunderphonics 96 (Seeland 515, Fony 069/96), released in 2001. 
is a moto perpetuo study somewhat similar to Chopin's Minute Waltz. It appeared in over 20 different editions in North America and Europe. ${ }^{15}$ Lavallée also wrote more ambitious pieces, including larger-scale instrumental forms and music theatre pieces, but these were not successful. Lavallée's failure as a composer despite his talent and ambition could be considered by comparing the musical life of nineteenth-century Canada to that of France, where contemporaries of Lavallée who were of equal or lesser talent flourished.

The case of Luigi von Kunits is in some respects opposite to that of Lavallée. He was a Viennese-born musician of modest talent, who knew both Bruckner and Brahms. His string quartet and viola sonata (published in the Canadian Musical Heritage series, vols. 13 and 23 respectively) are written in the style of Brahms (no commercial recording of either piece is available yet). Had he lived out his career in Europe, he would certainly be unknown to Canadians, and likely all but forgotten even in Europe. But his efforts in concert music performance and composition in Canada have kept his name alive, albeit on a modest level.

Beginning in the late-nineteenth century, prominent European composers begin to visit Canada with some regularity. Tchaikovsky befriended a Canadian bishop on his sea voyage to New York in 1891 (he wrote that he preferred the company of the bishop to that of the other first-class passengers, who were "banal American men and women-very dandified, but not in the least congenial") and he visited Canada briefly at Niagara Falls ("Canada is no longer America" he observed enigmatically) (Yoffe 1986, 43, 117). Liszt did not visit the New World, but he did have numerous contacts with Canadians, and his pupil Waugh Lauder championed the music of Wagner and Liszt in Canada through lecture-recitals. ${ }^{16}$

\section{TWENTIETH-CENTURY MUSIC}

Visits to Canada from prominent European composers continued: Ravel, Britten, and Stravinsky are notable examples. Ravel visited Vancouver, Toronto, and Montreal in 1928 and gave recitals of his own music in each city (Potvin 1988, 149-63). The Canadian mezzo-soprano Eva Gauthier is said to have brought Gershwin and Ravel together in New York in 1928, and she had close contacts with many leading composers of the first half of the twentieth century (Turbide 1986). Britten lived in Quebec in May and June of 1939; his Young Apollo, Op. 16 was the first work commissioned by the CBC (Kellogg 1988, 243-44) and his Canadian Carnival, Op. 19, incorporates various fiddle tunes and folksongs that he heard in Quebec (it concludes with a rousing treatment of "Alouette"). Stravinsky conducted suites from his ballets Firebird and Petrouchka with the Toronto Symphony on 5 January 1937, and during

15 Le papillon is available in Keillor (1983). The 25 volumes of the Canadian Musical Heritage Society contain over 1200 pieces of Canadian music ranging from short piano pieces and hymn tunes to large-scale orchestral and operatic works; much of this music dates from the nineteenth century.

16 See Pocknell $(1995,37-66)$. On Wagner's music in Canada before 1914, see two earlier articles in this journal: Lefebvre (1994, 60-76) and Morey (1998, 25-37). Lindsay Moore is currently working on a Ph.D. thesis on at the University of Toronto on Wagner reception in Canada. 
the 1960s he visited Toronto six times for recording, film, and concert projects (his last appearance ever as a conductor was in Toronto on 17 May 1967 for the Pulcinella Suite) ("Dossier" 1972, 15-82). Olivier Messiaen visited Canada on four occasions and counted numerous Canadians among his pupils (Boivin 1996). Most of the major twentieth-century techniques and styles are represented in the works of composers in this country, from atonality (in the works of Rodolphe Mathieu and of the Scriabin pupil Alfred La Liberté) onwards.

These are a few examples of ways in which Canadian music and musicians might feature in a music history survey course. ${ }^{17}$ The goal of this exercise is not to add a few token Canadian works to the canon. Instead, the inclusion of Canadiana in the music history curriculum invites consideration of the constructedness of the musicological "grand narrative ${ }^{18}$ " as presented in textbooks such as Grout/Palisca/Hanning, which in turn could lead to a discussion of the strategies by which entire repertoires (e.g. Canadian music, music by women composers) and ways of situating music within contemporary intellectual discourse are excluded and/or marginalized by this narrative. ${ }^{19}$

An alternative approach to the music history survey course was initiated by the ethnomusicologist Timothy Rice in the early 1980s at the University of Toronto. Instead of placing Canadian content at the end of the course, he placed it at the beginning. Under Rice, the first semester of the two-year core curriculum in music history began with Weinzweig, Somers, and Schafer, and continued with Oscar Peterson, Leroy Sibbles, Carol Pope, and Bruce Cockburn (Rice and Gutnik 1995, 239). ${ }^{20}$ Rice's decisions raise the issue of the inclusion of music from outside of the art music traditions (whether from jazz, popular, or world music repertoires) in music history survey courses. This has become an increasingly common strategy in recent years, as the disciplinary boundaries between musicology and ethnomusicology have become ever more blurred.

Ralph P. Locke argues strongly for the inclusion of "selected examples of non-Western and other musics (e.g. Western folk and popular musics, including music of the dance hall and the bourgeois parlour) into a course, or

17 I invite suggestions for improvements and other examples, and I will post the information to the Institute for Canadian Music web pages (www.utoronto.ca/icm) to make it readily available and easily revisable.

18 "Grand narrative" and "master narrative" are commonly used translations of Jean-François Lyotard's phrase grands récits (1984). Lyotard's book was the first to point out that the metanarratives commonly used in many intellectual disciplines were in an advanced state of collapse. See John Rink (2002) for a discussion of musicological "grand narratives" and how to teach around them in courses on twentieth-century music.

19 Citron (1993) provides a detailed and theoretically well informed study of how women have been excluded from the music history canon. An online bibliography on Canadian women in music compiled by Cheryl Gillard is available as part of the Library and Archives of Canada's "Celebrating Women's Achievements" web pages (see http:/www.nlc-bnc.ca/2/12/h12-221-e.html, accessed 8 February 2004). See also the web pages of the Association of Canadian Women Composers (http://www. composition.org/acwc/, accessed 8 February 2004).

20 One might argue that this was just relocating the Canadian music ghetto rather than rehabilitating it, but Rice's deeper engagement with a variety of Canadian musical materials in the course was certainly a step in the right direction. 
multi-course sequence, that is structured primarily as a chronological survey of Western art music" (Locke 2002, 32). Locke paints a rosy picture of the process, and believes that it helps to "reorient the listening patterns of the students, stimulate their thinking and shake them out of habitual value judgments" (Locke 2002, 39). But Ellen Koskoff, an ethnomusicologist and Locke's colleague at the Eastman School of Music, had quite the opposite experience. She came to regret her attempts to introduce ethnomusicological content into a Baroque music history survey course:

Soon, some of the students began to complain. They said I was infecting Western music with "creeping multiculturalism." They argued that other cultures' musics were irrelevant for them to learn because they would only be tested on Western music when applying to graduate schools. Furthermore, they only performed Western music in concerts, and until there was a sitar major, they would stick to their own tradition (Koskoff 1999, 557).

With the limited instruction time that is available in survey courses, each detour into non-traditional repertoire means that time will likely be taken away from the canonical works. To introduce a bit of gamelan music to help students appreciate Debussy's familiarity with that repertoire and the effect this may have had on his development as a composer means that less time will be available to devote to pieces of music by Debussy. Similarly, the introduction of Canadian content into a music history survey course means that less time will be available for the canon. The challenge, then, is to make the process of including Canadian content one that students find stimulating and engaging, rather than fruitless tokenism.

Whether or not non-canonic repertoire features in music history survey courses, the fact remains that the core curriculum of many Canadian institutions now includes an ethnomusicological component in which alternative narratives about music may figure with some prominence. A popular textbook for such courses is Kay Kaufman Shelemay's Soundscapes, which by comparison with the Grout/Palisca/Hanning text seems positively fulsome in its coverage of Canadian topics. In the Acknowledgments (Shelemay 2001a, xix) Shelemay refers to R. Murray Schafer (not surprising, given that he coined the word she uses as the title for the textbook), her case study of bagpipe music includes mention of the world champion Simon Fraser University Pipe Band (Shelemay 2001a, 54-55; the band is featured on the CD recordings that accompany the book), and her study of cajun music includes historical references to Acadia (Shelemay 2001a, 261-63). But more importantly, Shelemay provides an engaging and viable alternative to the grand narrative of traditional music history textbooks.

Shelemay breaks down musical barriers by deconstructing the language used to erect those barriers in the first place. As she explains in the Preface,

Because different musics coexist in everyday life, Soundscapes intentionally juxtaposes diverse musical traditions. Whenever possible, Soundscapes avoids disputed terminology, such as "world music" ... This book also avoids 
the old and tired oppositions, such as classical/vernacular, art/folk, traditional/popular, and Western/non-Western, that have for too long separated musical experiences and their study. (Shelemay 2001a, xiv)

So, out go the labels-art music, popular music, folk music, and so on-and instead music is considered in terms of various conceptual ideas that relate it to the "real world": music and migration, music and dance, music of worship and belief, and so on.

I have used Soundscapes for a largish (240 students) course for non-music majors, and found that it invites Canadianization of the content. As Shelemay states, "You can assign the Soundscapes text to your students as an organizing framework ... freeing you to focus in class on local musical resources and/or areas of your own expertise" (Shelemay $2001 \mathrm{~b}$, vii). Thus, for the introductory chapter, which includes a case study of Tuvan throat singing, I substituted a class on Inuit throat singing. We watched (twice) June in Povungnituk, a one-minute NFB film made in 1980 by the Abenaki film maker and musician Alanis Obomsawin, which shows two Inuit women in traditional dress performing throat singing outdoors (Obomsawin 1980). This was contrasted with a $\mathrm{CBC}$ television documentary on Inuit throat singers, in which the women perform on stage, and there are frequent intercessions from the musicologist Jean-Jacques Nattiez to explain the context and musical significance of Inuit throat singing (Inuit 1993). Next we listened to the song "Kajusita," first released in 1995 on the self-titled debut CD by Tudjaat, an Inuit singing duo consisting of Madeline Allakariallak and her cousin Phoebe Attagotaaluk. ${ }^{21}$ The song begins and ends with Inuit throat singing, and the text (three verses in English, one in Inuktitut) tells of the High Arctic exiles, a group of Inuit families who in 1953 were relocated from their home in northern Quebec to Resolute, NWT (now called Tudjaat, Nunavut). Finally we listened to a movement from the "radio documentary" Footprints in New Snow by the composer Christos Hatzis (2002), a collage that combines Inuit throat singing with electroacoustic music and sounds typical of and collected on Baffin Island (wind, bird calls, the crunch of walking on fresh snow, and so on). This study of Inuit throat singing in various contexts invited consideration of issues of the mediation of music, musical authenticity and appropriation, and transculturation.

For each section of Soundscapes, relevant Canadian examples can easily be found to substitute or complement the case studies that Shelemay presents. For Chapter Four, "The Study of Local Musics," we looked at the musical life of Toronto (the three examples in the textbook are Boston, Houston, and Juneau); to supplement the class lecture, students did their own case studies of a musical event in Toronto. The range of topics presented was impressive. I received essays on klezmer, Latin dance music, Irish traditional music, South Indian classical music, Russian Orthodox church music, buskers in the subway system, Qawwali music, taiko drumming, flamenco, music in peace/anti-war

21 "Kajusita" has been re-released many times, receiving perhaps the widest exposure on Heartbeat 2 (1998). 
demonstrations, music at an Ashkenazi Jewish wedding, music at a drag queen show, and so on. It was an incredibly vivid snapshot of the range of music making happening in Toronto in the spring of 2003.

I hope that these few suggestions might make a small contribution to the ongoing process of thinking about what we teach in survey courses and why we teach it. Perhaps too a dialogue can begin about the role that Canadian content can and should play in the general music history curriculum. That in turn may help to highlight the importance of music history pedagogy as a way of keeping our skills and our course content relevant to our students and respectful of the larger community in which we work.

\section{REFERENCE LIST}

Austin, William W. 1966. Music in the 20th Century from Debussy through Stravinsky. New York: W.W. Norton.

Beckwith, John. 1969. “About Canadian Music: The P. R. Failure.” Musicanada 21 (July-Aug.). Repr. in Beckwith 1997.

-1997. Music Papers: Articles and Talks by a Canadian Composer 1961-1994. Ottawa: Golden Dog Press.

Beckwith, John, and Frederick A. Hall, ed. 1988. Musical Canada: Words and Music Honouring Helmut Kallmann. Toronto: University of Toronto Press.

Beethoven \& Quebec. 1966. Montreal: McGill University Press.

Boivin, Jean. 1996. "Olivier Messiaen et le Québec: une présence et une influence déterminante sur la création musicale de l'après-guerre." Canadian University Music Review, no. 17/1: 72-97.

Bonds, Mark Evan. 2003. A History of Music in Western Culture. Upper Saddle River, N.J.: Prentice Hall.

Carruthers, Glen, and Gordana Lazarevich. 1996. A Celebration of Canada's Arts 1930-1970. Toronto: Canadian Scholars' Press.

Citron, Marcia J. 1993. Gender and the Musical Canon. Cambridge and New York: Cambridge University Press.

Clayton, Trevor. 2003. “A Journeyman's Passion and Canada's Triumph / Une passion d'artisan et le triomphe du Canada," National Library of Canada Bulletin 35, no. 4 (July-August). Available online at http://www.collections canada.ca/bulletin/015017-0403-01-e.html (accessed 23 July 2004).

Cook, Nicholas, and Mark Everist, ed. 1999. Rethinking Music. Oxford: Oxford University Press.

Diamond, Beverley. 1990. "Canadian Music Studies in University Curricula," Association for Canadian Studies ACS Newsletter 12, no. 3 (Fall): 16-18.

- 1994. "Narratives in Canadian Music History." In Canadian Music: Issues of Hegemony and Identity, ed. Beverley Diamond and Robert Witmer, 139-71. Toronto: Canadian Scholars' Press. Repr. in McGee. 1995, 273-305.

“Dossier Stravinsky-Canada 1937-1967." 1972. Les Cahiers canadiens de musique / The Canada Music Book no. 4 (Spring/Summer): 15-82. 
Elliott, Robin. 1990. "The String Quartet in Canada." Ph.D. thesis, University of Toronto. Available online at http://www.utoronto.ca/icm/thesis $1 . \mathrm{html}$ (accessed 8 February 2004).

Gallat-Morin, Élisabeth. 1981. Le livre d'orgue de Montréal. Facsimile. Outremont: Fondation Lionel-Groulx. Reissued in 1988. Paris: Aux Amateurs de livres; Montréal: Les Presses de l'Université de Montréal.

1988. Un manuscrit de musique française classique: Le livre d'orgue de Montréal, étude critique et historique. Paris: Aux Amateurs de livres; Montréal: Les Presses de l'Université de Montréal.

Gallat-Morin, Élisabeth, and Kenneth Gilbert. 1985-88. Livre d'orgue de Montréal : édition critique. 3 vols. Saint-Hyacinthe, Québec: Jacques Ostiguy.

Gallat-Morin, Élisabeth, and Jean-Pierre Pinson. 2003. La vie musicale en Nouvelle-France. Montréal: Septentrion.

Grout, Donald Jay and Claude V. Palisca. 2001. A History of Western Music. 6th ed. New York: W.W. Norton.

Haines, John. 1999. "Marius Barbeau and Jean Beck on Transcribing FrenchCanadian songs," ARSC Journal 30, no. 1 (Spring): 1-6.

- Forthcoming. "Marius Barbeau et le Moyen Âge." In Around and About Marius Barbeau: Writings on the Politics of Twentieth-Century Canadian Culture, ed. Lynda Jessup, Andrew Nurse, and Gordon Smith.

Hanning, Barbara Russano. 2002. Concise History of Western Music. 2nd ed. New York: W.W. Norton.

Hatzis, Christos. 2002. "Footprints in New Snow." Sixth movement of Footprints in New Snow on Everlasting Light-Footprints in New Snow. CBC Records MVCD 1156-2.

Inuit Throat Singers. 1993. CBC Arts and Entertainment. 13 minutes. Videocassette 4142.

"Kajusita." 1998. Heartbeat 2: More Voices of First Nations Women. Smithsonian Folkways CD 40455.

Kallmann, Helmut. 1960. A History of Music in Canada 1534-1914. Toronto: University of Toronto Press. Repr. in 1987 with list of amendments.

- 1971. "Beethoven and Canada: A Miscellany." Les Cahiers canadiens de musique / The Canada Music Book, no. 2. (Spring/Summer): 107-17.

Keillor, Elaine ed. 1983. Piano Music I, Canadian Musical Heritage 1. Ottawa: Canadian Musical Heritage Society.

Kellogg, Patricia. 1988. "Sounds in the Wilderness: Fifty Years of CBC Commissions." In Beckwith and Hall 1988, 239-61.

Koskoff, Ellen. 1999. "What Do We Want to Teach When We Teach Music? One Apology, Two Short Trips, Three Ethical Dilemmas, and Eighty-Two Questions." In Cook and Everist 1999, 545-59.

Lazarevich, Gordana. 1996. "The Role of the Canadian Pacific Railway in Promoting Canadian Culture." In Carruthers and Lazarevich 1996, 3-13. 
Leech-Wilkinson, Daniel. 2002. The Modern Invention of Medieval Music: Scholarship, Ideology, Performance. Cambridge: Cambridge University Press.

Lefebvre, Marie-Thérèse. 1994. "La musique de Wagner au Québec au tournant du XX $\mathrm{XX}^{\mathrm{e}}$ siècle." In Canadian University Music Review no. 14 (June): 60-76.

Locke, Ralph P. 2002. "What Chopin (and Mozart and Others) Heard: Folk, Popular, 'Functional,' and Non-Western Music in the Classic/Romantic Survey Course." In Natvig 2002, 25-42.

Lopinski, Janet, Joe Ringhofer, and Peteris Zarins. 2002-3. Exploring Music History: A Guided Approach. 3 vols. Mississauga, Ont.: Frederick Harris Music.

Lyotard, Jean-François. 1984. The Postmodern Condition: A Report on Knowledge, trans. Geoff Bennington and Brian Massumi. Minneapolis: University of Minnesota Press. Trans. from Lyotard 1979. La condition postmoderne: rapport sur le savoir. Paris: Éditions de Minuit.

McGee, Timothy J. 1985. The Music of Canada. New York : W.W. Norton. 1995. Taking a Stand: Essays in Honour of John Beckwith. Toronto: University of Toronto Press

McNaughton, Janet. 1984. "C. Marius Barbeau and the Origins Controversy," Canadian Folk Music Journal 12: 60-64. Available online at http://cjtm.icaap.org/content/12/v12art8.html (accessed 8 February 2004). Morey, Carl. 1998. "The Music of Wagner in Toronto before 1914." In Canadian University Music Review, no. 18/2: 25-37.

Morgan, Robert P. 1991. Twentieth-Century Music: A History of Musical Style in Modern Europe and America. New York: W.W. Norton.

Natvig, Mary ed. 2002. Teaching Music History. Burlington, Vt.: Ashgate. Obomsawin, Alanis, dir. 1980. Canadian Vignette: June in Povungnituk. National Film Board of Canada. Videocassette 113C 0180087.

Paul, Hélène, Louise Bail Milot, and Louise Hirbour. 1987. Initiation à la littérature musicale. Sainte-Foy, Québec: Le Griffon d'argile.

Pocknell, Pauline. 1995. "Liszt and His Canadian Circle." Journal of the American Liszt Society 38 (July-December): 37-66.

Poirier, Lucien. 1988. "La fortune de deux œuvres de Jean-Jacques Rousseau au Canada français entre 1790 et 1850." In Beckwith and Hall 1988, 60-66. Potvin, Gilles. 1988. "Maurice Ravel au Canada." In Beckwith and Hall 1988, 149-63.

Quesnel, Joseph. 1974. Colas et Colinette. Toronto: Gordon V. Thompson. Vocal score reconstructed by Godfrey Ridout.

-1992. Lucas et Cécile. Montréal: Doberman-Yppan. Vocal score realized by John Beckwith.

Rice, Timothy, and Tammy Gutnik. 1995. "What's Canadian about Canadian Popular Music?: The Case of Bruce Cockburn." In McGee. 1995, 238-56. Rink, John. 2002. "Teaching Music History (After the End of History): 'History Games' for the Twentieth-Century Survey." In Natvig 2002, 43-65. 
Roi, Micheline. 2003. "Canadian Music Courses at Canadian Universities," Canadian League of Composers Bulletin (Spring): 4-5. Available in PDF format from the Canadian League of Composers website at http://www.composition.org (accessed 8 February 2004).

Shelemay, Kay Kaufman. 2001a. Soundscapes: Exploring Music in a Changing World. New York: W.W. Norton.

- 2001b. Instructor's Manual-Soundscapes: Exploring Music in a Changing World. New York: W.W. Norton.

Turbide, Nadia. 1986. "Biographical Study of Eva Gauthier (1885-1958), First French-Canadian Singer of the Avant-Garde." Ph.D. thesis, Université de Montréal.

Yoffe, Elkhonon. 1986. Tchaikovsky in America: The Composer's Visit in 1891. New York: Oxford University Press.

\begin{abstract}
Canadian music is almost completely absent from university-level textbooks used in this country, most of which are published in the United States. Canadian content typically is added to a music history survey course, if at all, at the end of the chronological account. This article argues for a different approach, one in which Canadian content is integrated into the survey course from the medieval era to the present day. Introductory courses in ethnomusicology could also include Canadian music materials at many different points.
\end{abstract}

\title{
Résumé
}

La musique canadienne est presque complètement exclue des manuels utilisés au niveau universitaire, dont la plupart sont publiés aux États-Unis. Dans un cours d'introduction à l'histoire, si le contenu canadien s'y trouve, il est généralement annexé à la fin de l'exposé chronologique. Le présent article plaide en faveur d'une approche différente qui intégrerait le contenu canadien dans toutes les époques du cours d'introduction, de l'Antiquité à nos jours. Les cours de base en ethnomusicologie pourraient également aborder la musique canadienne à de nombreux moments. 